\title{
Comparison of the Effect of Three Food Diets Provided to Giant Tortoises (Chelonoidis guntheri and Chelonoidis vicina) Bred in Captivity at Isabela Island - Galápagos
}

\author{
Puga-Torres $\mathrm{BH}^{* 1}$, Morales-Arciniega $\mathrm{SM}^{1}$, Núñez $\mathrm{LFN}^{1,2}$, Carvajal-Mora $\mathrm{O}^{3}$, Santander-Parra $\mathrm{SH}^{2}$, and \\ Aragón-Vásquez $\mathrm{EF}^{1}$ \\ ${ }^{1}$ College of Veterinary Medicine, Central University of Ecuador, Jerónimo Leyton, Gatto Sobral, Quito, Ecuador \\ ${ }^{2}$ Department of Pathology, College of Veterinary Medicine, University of Sao Paulo Av. Prof. Dr. Orlando Marques \\ de Paiva, São Paulo, Brasil \\ ${ }^{3}$ Galapagos National Park - Responsible for the Ecosystem Process of the Galapagos National Park, Antonio Gil and \\ Los Flamencos, Isabela, Ecuador
}

${ }^{*}$ Corresponding author: Puga-Torres BH, College of Veterinary Medicine, Central University of Ecuador, Jerónimo Leyton s/n y Gatto Sobral, Quito, Ecuador, Tel: 593(2)2566160, E-mail: bpuga@uce.edu.ec

Citation: Puga-Torres BH, Morales-Arciniega SM, Núñez LFN, Carvajal-Mora O, Santander-Parra SH, et al. (2017) Comparison of the Effect of Three Food Diets Provided to Giant Tortoises (Chelonoidis guntheri and Chelonoidis vicina) Bred in Captivity at Isabela Island - Galápagos. J Vet Sci Ani Husb 5(2): 204. doi: 10.15744/2348-9790.5.204

Received Date: April 12, 2017 Accepted Date: May 23, 2017 Published Date: May 25, 2017

\begin{abstract}
Digestive strategies are considered a key factor for healthy growth and conservation of the Galapagos symbol animal. In the breeding center of Isabela Island there is no nutrition studies on giant tortoise bred in captivity, which are exclusively fed with otoy, yautia or malanga (Xanthosoma sagitifolium). In the present study we worked with 60 juvenile tortoise of Galapagos (Chelonoidis guntheri and Chelonoidis vicina), divided into 3 groups of 20 animals each. The diets used were: Diet A: mixture of cassava (Manihot esculenta), carrot (Daucus carota), passion fruit (Passiflora edulis), trunk, leaf and fruit of banana (Musa paradisiaca), otoy (Xanthosoma sagittifolium), guava (Psidium guajava), leaf and fruit of plum (Spondias movie), elephant grass (Pennisetum purpureum), king grass (Pennisetum purpureum hybrid), orange (Citrus aurantium), pineapple (Aranas comosus), potato (Solanum tuberosum), cabbage (Brassicao leacea), leucaena (Leucaena leucocephala), cut into small pieces and water ad libitum; Diet B: equal to diet A but assisted with the administration of vitamin supplements sprinkled in the food at a dose of $20 \mathrm{~g} / \mathrm{kg}$ of food, and water ad libitum; and Diet Control (exclusively otoy Xanthosoma sagittifolium). The tortoise were kept for 6 months with water and feed ad libitum with each of the diets. To determine the effect of the diets on the animals under study were made measurements of the carapace and weighing of the animals. After the 6-month of experimental period, the tortoises of the three groups did not present a difference statistically significant in increase weight or size $(\mathrm{P}>0.05)$ between the control group and the experimental diets. The present study shows that the diets A and B could be an alternative for the nutrition and maintenance of the Galápagos'tortoise in the centers of breeding in captivity.
\end{abstract}

Keywords: Galapagos Giant Tortoises; Alternative diets; Otoy or malanga

\section{Introduction}

Galapagos giant tortoises are the largest terrestrial chelonians in the world [1]. They are a prominent symbol of the archipelago and illustrate the influence of geological history and natural selection on the diversification of organisms, so they are recognized both for their uniqueness and for their contribution to the development of Darwin's natural selection theory [2]. Much of the success in maintaining and reproducing captive reptiles relies on a correct, healthy and balanced diet; their growth is characterized by many factors but depends mainly on food, climate and other environmental conditions [3]. The life span of the giant tortoises of Galapagos is greater than 100 years [4,5]. Good nutrition is the fundamental basis for the welfare of captive-bred animal species, especially if they are endemic and emblematic animals such as giant tortoises in the Galapagos, and even more so if they are vulnerable and considered endangered; Galapagos giants have largely declined their population since the European discovery of the islands in the 16th century, and the decline in populations has been estimated to have been 250,000 tortoise to between 8000 and 14000 animals in the 1970s [6]. In the Galapagos Islands there are several animal species that have been introduced by man and have been transformed into terrible plagues (swine, horses, cattle, rodents, felines, canines and ants), which compete for food or prevent the reproduction of Giant tortoises [7]. Tortoises populations declined further in the $20^{\text {th }}$ and $21^{\text {st }}$ centuries because of the impacts of introduced non-native animals; of the 15 generally recognized species, four were extinct during the historical period (that is, from 1535, but before the development of modern conservation programs) and another in 2012 with the death of Lonesome George, the sole survivor of Pinta Island; The remaining nine species are currently in danger of extinction [6]. 
As aforesaid, it was necessary to build breeding centers for giant tortoises in Galapagos, in order to be able to reproduce in captivity, and then release them in their areas of origin, in order to recover the wild populations of these reptiles emblematic of the islands.

At the breeding centers in Isabela island, there were no studies on the effect of non-traditional diets on giant captive-bred tortoise, which are only fed on otoy yautia or malanga (Xanthosoma sagittifolium), so it is very important, for the conservation of the animal symbol of Galapagos, to investigate this issue, because a monospecific diet is being provided, which is not advisable since no food can contain all the nutrients essential for the good feeding of an animal destined to the reproduction, in addition there is no studies on the nutritional values of otoy, nor have they been compared with the nutrients of plants normally consumed by tortoise in the wild (Puga and Carvajal, 2017 -unpublished data-). Although the majority of tortoises in the breeding center remain apparently healthy, there have been reproductive problems that may well be associated with inadequate nutrition (unpublished data). Also in this center have not been administered nutritional supplements of minerals and vitamins, which are essential for the good nutrition of the animals. It must be taken into account that the standard nutritional bases in different zoos and breeding sites of animals in captivity have been improved, partially through the adaptation of trial-error diets and partially through the application of scientific and research principles; for this reason the present work will lay the foundations and help to outline important principles regarding captive nutrition of the giant tortoises of Galapagos, looking for a better living condition and a proportioned growth of the tortoise, with an adequate amount of fresh food, with the correct balance of nutrients for good health and therefore for their well-being. In addition, it is thought that the breeding program will be improved in captivity, so that the breeding will be in the best conditions for copulation, egg laying and adequate growth of the newborn.

The formulation and testing of experimental diets proved to be important for large-scale screening of the green iguana (Iguana iguana) in Panama and Costa Rica, thousands of which have already been released in their natural environment [3]. Survival and growth of terrestrial iguanas (Conolophus subcristatus) raised in captivity in the Galapagos Islands was markedly improved through the elaboration of a complete feed based on locally available ingredients, this was essential for the continuation of the conservation program in which iguanas were repatriated to islands where populations had previously been exterminated [3].

The nutritional requirements of reptiles have not been correctly defined and research in this area has been limited, however there is some data that may help to transpose certain information (Table 1). The dietary requirements of captive herbivorous chelonians are the most complex [8].

\begin{tabular}{|c|c|}
\hline Nutrient & Quantity \\
\hline Crude protein & $30 \%$ \\
\hline Linoleic acid & $1,00 \%$ \\
\hline Arginine & $1 \%$ \\
\hline Isoleucine & $0,50 \%$ \\
\hline Lysine & $0,80 \%$ \\
\hline Methionine & $0,40 \%$ \\
\hline Methionine + Cystine & $0,75 \%$ \\
\hline Threonine & $0,70 \%$ \\
\hline Tryptophan & $0,15 \%$ \\
\hline Calcium & $0,80 \%$ \\
\hline Phosphorus & $0,50 \%$ \\
\hline Potassium & $0,40 \%$ \\
\hline Sodium & $0,20 \%$ \\
\hline Magnesium & $0,04 \%$ \\
\hline Manganese & $5 \mathrm{ppm}$ \\
\hline Zinc & $50 \mathrm{ppm}$ \\
\hline Iron & $60 \mathrm{ppm}$ \\
\hline Copper & $5 \mathrm{ppm}$ \\
\hline Iodine & $0,3 \mathrm{ppm}$ \\
\hline Selenium & $0,3 \mathrm{ppm}$ \\
\hline Rivoflavin & $2 \mathrm{ppm}$ \\
\hline Pantothenic Ácid & $10 \mathrm{ppm}$ \\
\hline Niacin & $10 \mathrm{ppm}$ \\
\hline Vit. B12 & $0,020 \mathrm{ppm}$ \\
\hline Choline & 1250ppm \\
\hline Biotin & $70 \mathrm{ppm}$ \\
\hline
\end{tabular}




\begin{tabular}{|c|c|}
\hline Nutrient & Quantity \\
\hline Folacin & $200 \mathrm{ppm}$ \\
\hline Thiamine & $1 \mathrm{ppm}$ \\
\hline Pyridoxine & $1 \mathrm{ppm}$ \\
\hline Vitamin A & $5000 \mathrm{UI} / \mathrm{kg}$ \\
\hline Cholecalciferol & $500 \mathrm{UI} / \mathrm{kg}$ \\
\hline Vitamin E & $150 \mathrm{UI} / \mathrm{kg}$ \\
\hline
\end{tabular}

Table 1: Nutrient concentration for herbivorous reptiles

Cayot (1999), indicates that tortoises are vegetarian and can eat about 50 different species of plants, including venomous apple or manzanillo (Hippomanea mancinella), endemic guayabillo (Psidium galapageium), fern (Azolla microphylla), bromediaria (Tillandsia insulares) to more than countless fruits and cacti. In a study of Alcedo Volcano on Isabela Island, [9] indicate that endemic guayabillo (Psidium galapageium) is a major food source during the month of November, Sida spp. Are the most important foods in the tortoise diet throughout the dry season. Márquez Cruz (1999), describes the Galapagos tortoise as an opportunistic herbivore with a predilection for herbs, fruits and cacti, and, mentions that in the natural state, the tortoise of arid and dry areas mainly eat fruits and Cactus Opuntia (Opuntia echios). Merlen (1999) [5] while in mountainous areas their diet is much more varied and consume herbs and various plants. Other authors indicate that wild tortoises in Galapagos almost certainly consume large amounts of low energy forage, and although they also like fruits or cushions of Opuntia cactus [10] or other rich food, but they are consumed in rare occasions [11].

Hunter et al. (2013) mention that tortoise with domed shells settle remains at higher and more humid elevations than saddleshaped shells; the latter select areas with high densities of arboreal cacti (Opuntia galapageia); these animals cannot submerge in the water and that they can hardly swim, and have a distribution linked to the areas with vegetation of the slopes or tops of the volcanoes present in the islands [1].

For Ferrer et al, 2004, no other terrestrial vertebrate increases its weight from birth to adult by a factor of 3000 times. This unique phenotype allows tortoises to adapt their growth to their feeding conditions. Calcium $(\mathrm{Ca})$ and phosphorus $(\mathrm{P})$ are very important minerals in reptile feeding, but many diets are still not balanced; to achieve optimal growth, including a healthy skeleton and a strong shell, a balanced supply with these essential minerals is indispensable [12]. The aim of the present study was to compare the influence of 3 alternative dietary diets about weight and growth of giant tortoise (Chelonoidis guntheri and Chelonoidis vicina) breeding in captivity on Isabela Island - Galapagos, Ecuador.

\section{Materials and Methods}

The present study was carried out at the Arnaldo Tupiza Giant Tortoise Breeding Center in Puerto Villamil on Isabela Island, which is located in latitude south: $00^{\circ} 94.6^{\prime} 84.7$ and latitude west: $90^{\circ} 97^{\prime} 37.9$.

\section{Field materials}

60 giant tortoises from 2 to 4 years of age were divided into three groups of 20 animals; Traditional Diet (group 1 or control group); Diet A (group 2) and Diet B (group 3); was not there environmental variation in the study groups, so it did not influence food behavior.

The Traditional Diet (group 1) is based on otoy, yautia or malanga (Xanthosoma sagittifolium) and water ad libitum; the animals were placed in a corral of $280 \mathrm{~cm}$ long by $240 \mathrm{~cm}$ wide, soil floor and at an altitude of $80 \mathrm{~cm}$ from the ground; 20 animals of the subpopulation of San Pedro (Chelonoidis guntheri) (Figure 1-Right). The otoy is a plant widely distributed in the American continent.
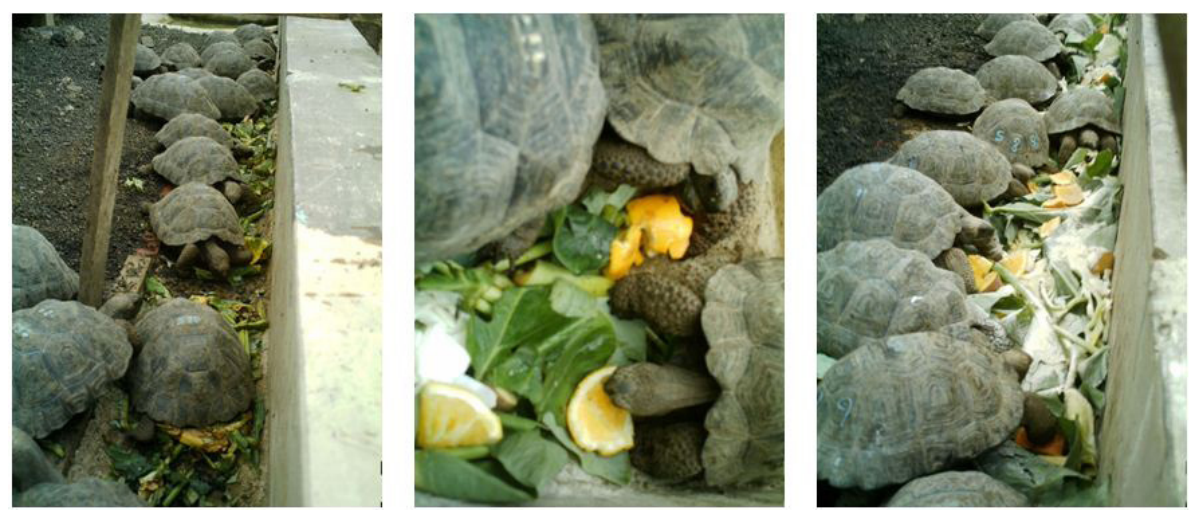

Right: Giant tortoises fed with traditional diet (group 1)

Middle: Giant tortoises fed with Diet A (group 2)

Left: Giant tortoises fed with Diet B (group 3)

Figure 1: Diets of the Giant tortoises of Galapagos in study 
The alternative diets consisted of several plants, fruits and vegetables that exist in abundance in the island and some are pests or are not endemic to Galapagos, with this did not alter the normal flora of the archipelago and somehow eliminated the excesses that exist the same (Table 2).

\begin{tabular}{|c|c|}
\hline \multicolumn{2}{|c|}{ Diets A and B } \\
\hline Common Name & Scientific Name \\
\hline Yucca & Manihot esculenta \\
\hline Carrot & Daucus carota \\
\hline Passion fruit & Passiflora edulis \\
\hline Banana & Musa paradisiaca \\
\hline Trunkand leaf of banana & Musa paradisiaca \\
\hline Otoy, yautia or malanga & Xanthosoma sagittifolium \\
\hline Guava & Psidium guajava \\
\hline Plum & Spondias movii \\
\hline Leaf of plum & Spondias movii \\
\hline Elephant grass & Pennisetum purpureum \\
\hline King grass & Pennisetum purpureum hibrido \\
\hline Orange & Citrus aurantium \\
\hline Pineapple & Ananas comosus \\
\hline Potato & Solanum tuberosum \\
\hline Cabbage & Brassica oleacea \\
\hline Leucaena & Leucaena leucocephala \\
\hline
\end{tabular}

Table 2: Foods used in diet A and B (Diet B was added a vitamin supplement)

Diet A was administered in small pieces along with water ad libitum; The animals were placed in corral (Figure 1-middle) of 460 $\mathrm{cm}$ long by $130 \mathrm{~cm}$ of width, ground floor and to an altitude of $80 \mathrm{~cm}$ of the ground and provided with cement feeder with form of canoe; 17 animals of the subpopulation of Cazuela (Chelonoidis guntheri) and 3 of the subpopulation of San Pedro (Chelonoidis guntheri).

Diet B was administered in small pieces, aided by the administration of vitamin supplements (CALFOVIT: Registry No. 1ABD5885-AGROCALIDAD, developed by INDUSTRIAL VETERINARIA SA - Spain) sprinkled in the food at a dose of $20 \mathrm{~g} / \mathrm{kg}$ of food and water ad libitum; The animals were located in a corral (Figure 1-left) with the same dimensions and characteristics described above; were located 19 animals of the subpopulation of Cinco Cerros (Chelonoidis vicina) and 1 of the subpopulation of Roca Union (Chelonoidis guntheri).

The tortoises under study had from 2 to 4 years old, of sex not determined, and were divided into 3 groups of 20 animals each housed in separate pens and provided with the right conditions for thermoregulation with direct sunlight and water at will (the three groups have similarly aged tortoises) with average temperature of $26^{\circ} \mathrm{C}$ range during the study period. All tortoises were active and apparently healthy throughout the study, which lasted for 6 months. The food was administered on Mondays, Wednesdays and Fridays at 8:00 a.m. and consumption observations were made at 4:00 p.m.

\section{Data collection}

In the chelonians under study, growth and monthly weight gain was evaluated by measuring with tape measure and monthly individual weighing of each Galápago tortoise. The evaluation was carried out through of the comparison of data taken from the two treatments under study vs those of the control group. Data collection was performed on the $5^{\text {th }}$ day of each month, beginning on May 5 and concluding on October 5.

\section{Measurement of the carapace}

Data were taken as follows: Curved length (Figure 2-right): measured from the center of the supracaudal plate, at the back of the carapace, through the vertebral plates, to the junction of the nuchal plates, at the back of the carapace.

Curved width (Figure 2-middle): measured from the junction between the dome and the plastron on the left side of the animal, passing through the center of the third vertebral plate, to the junction of the dome and plastron on the right side of the carapace.

Straight length of the plastron (Figure 2-left): measured from the union of the gular scutes in the anterior part of the plastron, until the union of the anal scutes in the posterior region of the plastron. Chiari \& Claude (2011) [13] indicate that despite the shared similarities of growth patterns and morphological changes observed during growth, different tortoises species and different sexes 
differ by shell shape.
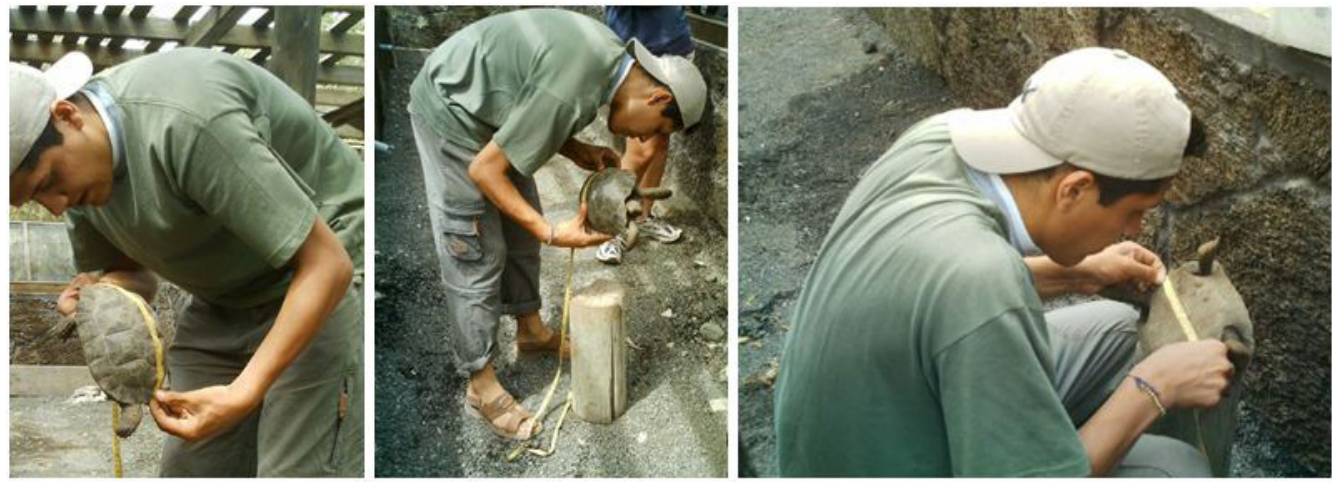

Right: Curved length

Middle: Curved width

Left: Straight length

Figure 2: Galapagos giant tortoise shell measurement

Weighing: The weight of the animals was obtained by turning the animal on a balance, that is to say, with the shell seated on the base of the same (Figure 3-right).
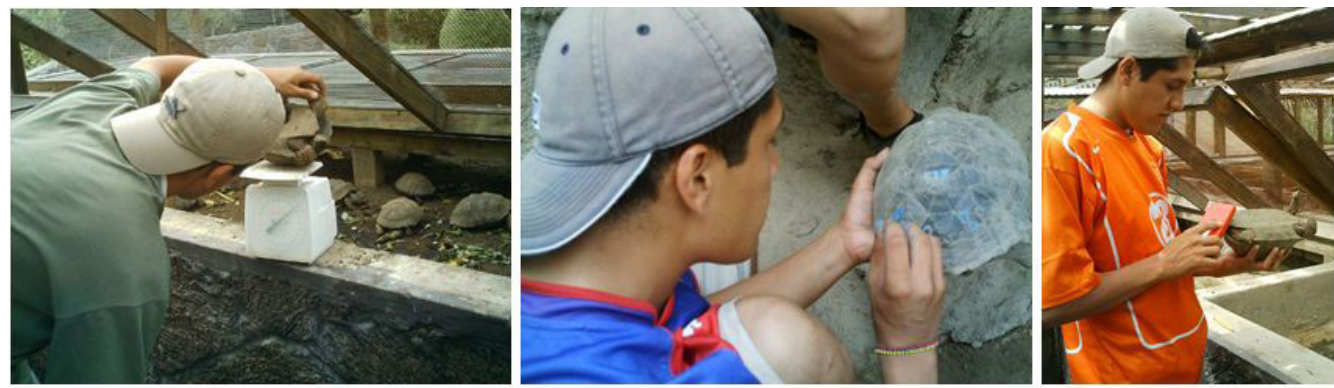

Right: Weighing

Middle: Marking with colored

Left: Marking with PIT (Passive Integrated Transducer)

Figure 3: Weighing and Marking of Galapagos giant tortoises in study

Marking: The tortoise were marked with colored enamel paint according to the population ( Red = San Pedro, Blanco = Cazuela, Blue $=$ Roca Unión, Ligth blue $=$ Cinco Cerros) (Figure 3-middle). Tortoises were also marked by subcutaneous implantation of the Passive Integrated Transducer (PIT) microchip in the left femoral region (Figure 3-left).

\section{Statistical analysis}

Statistical analysis was performed in the SPSS v22.0 package program. To establish the behavior of the weight (initial weight - final weight) and measures of the carapace (long straight, long curved and curved width) according to the type of treatment used, a description of the central tendency measures for each intervention was calculated by averaging and standard deviation. ANOVA and Duncan tests were performed for the weight variables and final shell measurements between the groups under study, with their respective confidence interval at $95 \%$ with $\mathrm{p}<0.05$.

Correlation (r), and Regression were also determined to determine that there is concordance between the 2 variables in terms of weight gain and carapace measurements, both in the control group and in the two experimental groups.

\section{Results}

The food was provided to Galapagos giant tortoises, aged 2 to 4 years, during six months of research; 6 measurements and weights of each tortoise of the three diets were carried out at fifth day of each month, showing that no statistically significant differences were obtained between the control group and the experimental diets. Was not determined the calorie content of the diets. Data used to determine the consumption of each group under study, based on the comparison of the food provided and the surplus food. The supply of the food was done once the cleaning of the feeders and the floor were finished, to avoid that the food was placed on the leftovers of the previous feeding or on the tortoise's dejections. The amount of food administered was $4 \mathrm{~kg} /$ corral, for all groups.

The administration of alternative diets in juvenile tortoise did not result in a significant increase in their weight and size, nor even in group 3 that received mineral vitamin supplementation. During the research period, the juvenile tortoises of the three groups did not present an increase in weight and size (Table 3), which was verified using the statistical analysis of variance method 
(ANOVA), at 1 and 5\%, by which the three treatments were compared and based on this it was established that there are no significant differences between these treatments during the six months of the study. This was also confirmed using the 1 and 5\% statistical method of DUNCAN. Correlation ( $r$ ) is very close to $1(0.98)$ in the three treatments, which shows that there are large changes in the weight of the animal as time passes. It was also found that there is a concordance between the two variables in terms of increase, both in the control group (Group 1) and in the two experimental groups (Group 2 and 3).

\begin{tabular}{|c|c|c|c|c|}
\hline \multicolumn{5}{|c|}{ Group 1} \\
\hline Month & $\begin{array}{l}\text { Curved length } \\
(\mathrm{cm})\end{array}$ & $\begin{array}{c}\text { Curved width } \\
(\mathrm{cm})\end{array}$ & $\begin{array}{c}\text { Straight } \\
\text { length }(\mathrm{cm})\end{array}$ & Weight (g) \\
\hline 1 & 25.37 & 26.30 & 18.57 & 1477.50 \\
\hline 2 & 25,77 & 26,595 & 19,04 & 1552,5 \\
\hline 3 & 26,095 & 27,135 & 19,32 & 1582,5 \\
\hline 4 & 26,43 & 27,315 & 19,465 & 1620 \\
\hline 5 & 26,67 & 27,675 & 19,645 & 1735 \\
\hline 6 & 26,91 & 28,03 & 19,875 & 1755 \\
\hline \multicolumn{5}{|c|}{ Group 2} \\
\hline Month & $\begin{array}{l}\text { Curved length } \\
(\mathrm{cm})\end{array}$ & $\begin{array}{l}\text { Curved width } \\
(\mathrm{cm})\end{array}$ & $\begin{array}{c}\text { Straight } \\
\text { length }(\mathrm{cm})\end{array}$ & Weight (g) \\
\hline 1 & 25,835 & 26,15 & 18,57 & 1535,00 \\
\hline 2 & 26,355 & 26,405 & 19,13 & 1590 \\
\hline 3 & 26,72 & 26,955 & 19,42 & 1607,5 \\
\hline 4 & 26,94 & 27,325 & 19,575 & 1687,5 \\
\hline 5 & 27,33 & 27,635 & 19,755 & 1815 \\
\hline 6 & 27,84 & 28,03 & 20,13 & 1842,5 \\
\hline \multicolumn{5}{|c|}{ Group 3} \\
\hline Month & $\begin{array}{l}\text { Curved length } \\
(\mathrm{cm})\end{array}$ & $\begin{array}{l}\text { Curved width } \\
(\mathrm{cm})\end{array}$ & $\begin{array}{c}\text { Straight } \\
\text { length }(\mathrm{cm})\end{array}$ & Weight (g) \\
\hline 1 & 24,765 & 26,20 & 18,06 & 1395,00 \\
\hline 2 & 24,975 & 26,4 & 18,21 & 1432,5 \\
\hline 3 & 25,17 & 26,885 & 18,425 & 1450 \\
\hline 4 & 25,715 & 27,175 & 18,725 & 1485 \\
\hline 5 & 26,07 & 27,665 & 18,95 & 1655 \\
\hline 6 & 26,55 & 28,15 & 19,205 & 1692,5 \\
\hline
\end{tabular}

Table 3: Results, on average, of weight and measures of Group 1, 2 and 3

By means of this statistical method it was possible to determine that there is concordance between the 2 variables in terms of increase, both in the group (negative control) and in the two experimental groups.

At the beginning of the study the selected groups were found to have a weight average of 1469 grams, with a range of 800 grams the lowest and 3200 grams the largest. The daily weight gain (average for each group) is $0.0018 \mathrm{~kg}(1.8 \mathrm{~g}) 0.0020 \mathrm{~kg}(2.0 \mathrm{~g}), 0.0019 \mathrm{~kg}$ $(1.9 \mathrm{~g})$, in the control negative group tortoise, diet A and diet B, respectively. Although there are no significant differences marked but a small gain greater weight in the group 2 (Diet A) of the treatments is observed.

\section{Discussion}

In all the groups of the present study, the average of initial and final weight and growth did not show statistically large differences between the three treatments, neither in the initial data nor in the final data. There were no marked differences in weight and size among the 3 treatments, this could be explained by the fact that the period of investigation was very short in order to determine significant differences between the 3 diets since the metabolism, such as growth and weight gain of Tortoise are very slow, because they are poikilotherms, that is, they cannot control their body temperature, but it depends on the room temperature, and their metabolic rate is directly proportional to body temperature [14]. Due to the small percentage of the coefficient of variation (Cv), it can be seen that the groups are homogeneous in their values of shell and weight measurements, so that the treatments and the group negative control were appropriate for the investigation.

Although the objectives of the present study were to compare the influence of weight and growth on alternative diets in giant tortoise of the breeder Center, and although there are no statistically significant differences regarding weight gain and increase in size, but perhaps from the nutritional point of view tortoises of groups 2 and 3 could be in better conditions than those of the 
control group and may have better options to reproduce and survive when they are repatriated. Likewise, these alternative diets can be used without inconvenience if the ecosystem of the tortoises is affected, for example, product of constant volcanic eruptions that occur in the archipelago, which depending on their magnitude, can devastate large areas of the Islands, and endanger the life of tortoises; with this research, these alternative diets could keep alive and well-nourished tortoises in captivity.

Galapagos giant tortoises show an efficiency digestion similar to the fermenting mammals of the large intestine (domestic horses, Asian elephants, Indian rhinoceroses) on a diet of hay and concentrates [15].

In nutrition of giant tortoises, as described by Furrer et al., in 2004, is not recommended diets in which there is an increase in exaggerated size of the tortoises, either because they develop an early sexual maturity, so they will have lower life expectancy or because they may develop pathological problems such as pyramiding, metabolic disease of the bone, kidney disease, Gut and joint, etc., or because the tortoises may be too large for the environment of their island of origin; so the present study could be favorable because tortoises are provided with a nutritionally better diet without an exaggerated increase in their weight and size that could cause the above mentioned problems, although further studies are required to verify this.

Likewise, as mentioned by Liesegang, et al. 2001, calcium (Ca) and phosphorus (P) are very important minerals in reptile nutrition since the increase of $\mathrm{Ca}$ concentrations in the diet led to an increase in the apparent digestibility of $\mathrm{Ca}, \mathrm{Mg}$, and $\mathrm{P}$.

Therefore these tested diets would be of great help for the maintenance of giant tortoises in captivity, not only those that are raised in Galapagos, but also those that are kept in captivity in other places of the world, since to provide a more range variety of food allows tortoise to have greater control over nutrient consumption and improve their nutritional balance.

In addition, offering always the same food could lead to reproductive and health problems (unpublished data), although it is possible that the conditions of the Galapagos Islands may give advantage to smaller tortoise to survive in difficult times as long droughts. It should also be taken into account that the natural conditions in which giant tortoise develop in their wild state are very adverse compared to the conditions that are provided in captivity, and should also be considered to be undergoing major changes in their diet (food to which the tortoise were kept and survived for hundreds of years), which could later affect their eating behavior, since tortoise could be migrate to different places in search of the food they were accustomed to eat in captivity. These migrations evidently occur, as determined by other studies where showing that some adult Galapagos tortoises, both sexes, can move up and down at a gradient altitude in response to changes in dynamics of vegetation [16]. A key issue, which is still under analysis according to [6] is whether the reduction of the wild tortoises population on the islands led to changes in the geographical distribution of giant tortoises or their use of Habitat, and what impacts they caused.

In this regard, [17] indicate that resource distribution and food selection are fundamental to ecology, life history, physiology, population dynamics, and conservation of animals; so in Galapagos introduced plants are changing the feeding dynamics of herbivores in many ecosystems often with unknown consequences; Giant tortoises, like many herbivores, undertake migrations along elevation gradients dependent on variability in vegetationandcourse of a year, specifically during periods of motivated [18].

Galapagos juvenile giant tortoises should have as raw fiber levels of 30-40\% on a dry matter basis [14]. Also, an excess diet of protein could generate a rapid growth, and could reach an earlier sexual maturity with a shorter life expectancy [19]. Increased crude fiber results in reduced digestibility [14] which could be of benefit to such tortoise.

The duration of 6 months of treatment could be very little in relation to the slow growth of the chelonians, reason why this work constitutes a good basis for future research in the field of nutrition and conservation of giant tortoises in captivity, which can contribute to design a new and efficient nutrition program in all giant tortoise of the breeding center, since the current feeding system, which uses a single food, could be deficient (unpublished data), influencing negatively the correct nutrition and reproduction of the animals and therefore in their condition of life.

\section{References}

1. Beheregaray LB, Gibbs JP, Havill N, Fritts TH, Powell JR, et al. (2004) Giant tortoises are not so slow : Rapid diversification and biogeographic consensus in the Galápagos. PNAS 101: 6514-9.

2. Poulakakis N, Glaberman S, Russello M, Beheregaray LB, Ciofi C, et al. (2008) Historical DNA analysis reveals living descendants of an extinct species of Galápagos tortoise. Proceedings of the National Academy of Sciences of the United States of America 105: 15464-9.

3. Parham JF (2008) Rediscovery of an "extinct" Galápagos tortoise. Proceedings of the National Academy of Sciences of the United States of America 105: 15227-8.

4. Goldstein S (1974) Aging in vitro Growth of Cultured Cells from the Galapagos Tortoise. Experimental Cell Research 83: 297-302.

5. Merlen G (1999) [The kingdom of the tortoise returning to its golden age]. (F. C. Darwin, Ed.) (First). Puerto Ayora. Puerto Ayora.

6. Froyd CA, Coffey EED, van der Knaap, Willem O, van Leeuwen, et al. (2014) The ecological consequences of megafaunal loss: Giant tortoises and wetland biodiversity. Ecology Letters 17: 144-54.

7. Aiello S (2000) [The Merck Veterinary Manual]. (Editorial Oceano, Ed.) (Quinta). Barcelona.

8. Márquez C, Cayot L, Rea S (1999) [Breeding giant tortoises in captivity]. (A. E. F. C. Darwin, Ed.) (Primera). Puerto Ayora.

9. Lynn E . Fowler De Neira, Mark K. Johnson (2016) Diets of Giant Tortoises and Feral Burros on Volcan Alcedo, Galapagos. The Wildlife Society 49: 165-9.

10. Hunter EA, Gibbs JP, Cayot LJ, Tapia W (2013) Equivalency of Galápagos Giant Tortoises Used as Ecological Replacement Species to Restore Ecosystem Functions. Conservation Biology 27: 701-9. 
11. Hairston C, \& Burchfield PM (n.d.). at the Gladys Porter Zoo.

12. Liesegang A, Hatt JM, Nijboer J, Forrer R, Wanner M, et al. (2001) Influence of different dietary calcium levels on the digestibility of Ca, Mg, and P in captiveborn juvenile Galapagos giant tortoises (Geochelone nigra). Zoo Biology 20: 367-74.

13. Chiari Y, Claude J (2011) Study of the carapace shape and growth in two Gal??pagos tortoise lineages. J Morphol 272: 379-86.

14. Bargalló F, Moura AS, García C, Grifols J, Martínez A, et al. (2016) Hibernation in terrestrial and aquatic turtles. Zoologic Badalona Veterinary 74: 30-8.

15. Hatt JM, Clauss M, Gisler R, Liesegang A, Wanner M (2005) Fiber digestibility in juvenile galapagos tortoises (Geochelone nigra) and implications for the development of captive animals. Zoo Biology 24: 185-91.

16. Blake S, Yackulic CB, Cabrera F, Tapia W, Gibbs JP, et al. (2013) Vegetationdynamics drive segregation by body size in Galapagos tortoises migrating across altitudinal gradients. J Ani Ecol 82: 310-21.

17. Stephen Blake, Anne Guézou, Sharon L. Deem, Charles B. Yackulic, Fredy Cabrera (2015) The Dominance of Introduced Plant Species in the Diets of Migratory Galapagos Tortoises Increases with Elevation on a Human-Occupied Island. J Biotropica 47: 246-58.

18. Bastille-Rousseau G, Yackulic CB, Frair JL, Cabrera F, Blake S (2016) Allometric and temporal scaling of movement characteristics in Galapagos tortoises. J Ani Ecol 85: 1171-81.

19. Furrer S, Hatt Jean, Snell H, Márquez Cruz, Honnegger R, et al. (2004) Comparative study on the grown of juvenile Galapagos giant tortoises (Geochelone nigra) at the Charles Darwin Research Station (Galapagos Island, Ecuador) and Zoo Zurich (Zurich Switzerland). Zoo Biology 23: 177-83.

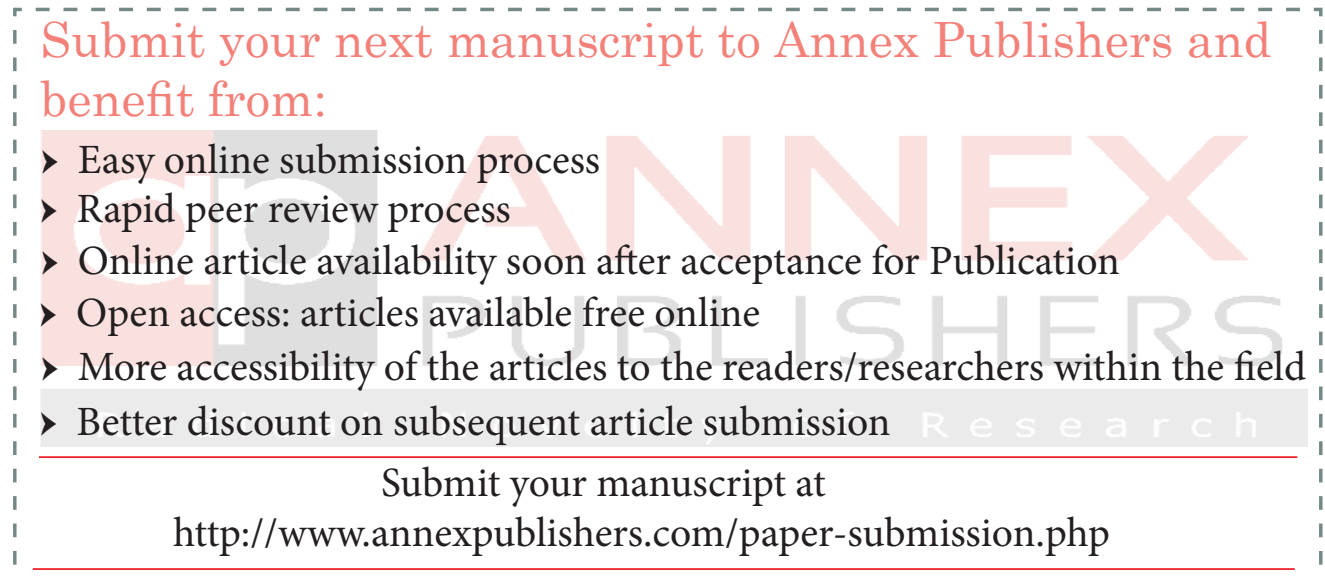

